\title{
Prevalence and Pattern of Electrolyte Imbalance in Hypertensives Admitted in Nigerian Teaching Hospitals
}

\author{
Akinsanya Olusegun-Joseph ${ }^{1}$, Bolanie Okunowo ${ }^{1}$, Kamilu Karaye², Adeseye Akintunde ${ }^{3}$
}

1. Department of Medicine, College of Medicine, University of Lagos \& Lagos University Teaching Hospital, Lagos, Nigeria

2. Department of Medicine, Bayero University \& Aminu Kano Teaching Hospital, Kano, Nigeria

3. Department of Medicine, Ladoke Akintola University of Technology (LAUTECH) \& LAUTECH Teaching Hospital, Ogbomoso, Nigeria.

\section{Corresponding author:}

A.D. Olusegun-Joseph

Department of Medicine, College of Medicine,

University of Lagos \& Lagos University Teaching Hospital,

Lagos, Nigeria.

Email: danielsangrt@gmail.com.

\author{
Abstract \\ Background \\ Hypertension not only predisposes to cardiovascular diseases, it is also associated with electrolyte imbalances (Els), which in \\ most cases subtly impacts on morbidity and mortality. We aimed to determine the prevalence and pattern of El in hospitalized \\ hypertensives from three teaching hospitals in Nigeria.
}

\section{Methods}

This was a retrospective study of hypertensive patients who were admitted in three teaching hospitals in the cities of Lagos, Kano and Ogbomosho, Nigeria. Medical records and serum electrolyte results done at the point of admission were retrieved and analyzed.

Results

159 admitted hypertensive patients who had analysis of their electrolytes were recruited of which $106(66.7 \%)$ were males, while $53(33.3 \%)$ were females. Majority of patients $(138\{86.8 \%\})$ had at least one El, while only $21(13.2 \%)$ had normal electrolytes. $39(24.5 \%)$ patients had more than two Els; 55(34.6\%) had two Els, while $44(27.7 \%)$ had one El. The commonest electrolyte abnormality was hyponatremia seen in $63(39.6 \%)$ patients, followed by hypokalemia, reduced bicarbonate and hypochloremia found in $58(36.5 \%), 53(33.3 \%)$, and $40(25.2 \%)$ respectively.

El was more prevalent among females (96.2\% vs $82.1 \%$ in males; $p=0.002)$, patients who had tachycardia $(94.3 \%$ vs $80.9 \%$ of patients without tachycardia; $p=0.042)$ and those with elevated diastolic blood pressure (DBP) $(p=0.034)$.

\section{Conclusions}

Els are very common among hospitalized hypertensive patients, with most of them having multiple derangements. El was more prevalent in females, patients with tachycardia and elevated DBP.

Keywords: Hospitalized hypertensive; electrolyte imbalances; Potassium; Sodium; bicarbonate; Chloride.

Citation: $\quad$ Olusegun-Joseph A, Okunowo B, Karaye K, Akintunde A. Prevalence and Pattern of Electrolyte Imbalance in Hypertensives Admitted in Nigerian Teaching Hospitals. International Cardiovascular Forum Journal 2020;21:22-29. DOI: $10.17987 /$ icfj.v21i0.741.

\section{Introduction}

Hypertension remains the most important risk factor for cardiovascular diseases (CVD), being a leading cause of stroke, heart failure, ischemic heart disease (IHD), renal failure, peripheral arterial disease, and visual impairment [1]. It is also a major reason for medical admissions, morbidity and mortality

[2,3]. Chronic, uncontrolled hypertension, however, not only predisposes to cardiovascular diseases, it is also associated with $\mathrm{El}$, which in most cases subtly impacts on prognosis, morbidity and mortality [4-6]. 
The pathophysiology of hypertension as well as the drugs used in the treatment and the complications of hypertension all have electrolyte input as modulators [4,7-8]. Notable in the pathophysiology of hypertension is the Sympathetic and Renin-Angiotensin-Aldosterone-System (RAAS) which when activated cause vasoconstriction, increased cardiac output, other hemodynamic alterations, sodium and water retention. $[7,9]$ Drugs used in hypertension play important role in electrolyte homeostasis, with most of them predisposing to El [8-11].

Other contributing factors to electrolyte imbalance in chronic hypertensives includes, increased salt intake,[5,7] comorbidities such as diabetes mellitus, $[7,12]$ obesity $[7,13]$ and hypertensive complications $[4,7]$.

There are many studies on complications of hypertension; however, studies on El in hypertensives are scanty, especially in this part of the world. Previous studies have described El in different cohorts, with most investigating specific electrolytes in diabetes mellitus, [12] heart failure, [14] renal disease,[15] stroke, [16] and patients admitted into the emergency department [17]. Searching through literature it is obvious that there are obvious gaps that need to be addressed with regards to El in hospitalized hypertensives. We hope this study will address some of these and add valuable information to this important associate of hypertension.

This study was aimed at assessing the prevalence and pattern of Els in hypertensives admitted in three teaching hospitals in Nigeria.

\section{Method}

This was a retrospective study carried out among hypertensive patients admitted in the medical wards in three teaching hospitals in Nigeria: Lagos University Teaching Hospital (LUTH), Aminu Kano Teaching Hospital (AKTH) and Ladoke Akintola University of Technology Teaching Hospital (LAUTECH TH), Ogbomoso.

Medical records including electrolyte parameters of the patients were retrieved and analyzed. The electrolytes evaluated were serum Sodium, Potassium, Chloride, and Bicarbonate. Serum Calcium, Magnesium, Phosphorus and other trace elements were excluded because most of the patients did not have such result among the panel of electrolytes requested. The data retrieved included demographics, clinical notes, diagnosis, investigations, antihypertensives medications and complications.

Hypertension was defined in this study as sustained systolic and/ or diastolic blood pressure (SBP and DBP respectively) of $\geq 140$ and or $90 \mathrm{mmHg}$ respectively, or its documented history, or if a patient was on any antihypertensive medication even if BP was normal [20].

Hypernatremia and hyponatremia are defined as serum sodium greater and less than $135-145 \mathrm{mmol} / \mathrm{l}$ respectively [21] .

Hyperkalemia and hypokalemia are defined as serum potassium greater and less than $3.5-5.0 \mathrm{mmol} / /$ respectively [21].

Hyperchloremia and hypochloremia are defined as serum chloride greater and less than $96-107 \mathrm{mmol} / \mathrm{l}$ respectively [22].

Elevated serum bicarbonate (Alkalosis) and reduced bicarbonate (acidosis) are defined as serum bicarbonate $(\mathrm{HCO} 3)$ greater and less than $22-30 \mathrm{mmol} / /$ respectively [21].

\section{Results}

In this study, 159 admitted hypertensive patients whose electrolytes parameters were available were analyzed, 21 $(13.2 \%)$ of which had normal electrolytes, while $138(86.8 \%)$ had at least one deranged electrolyte. Males were 106 (66.7\%), while $53(33.3 \%$ ) were females. The elderly ( $\geq 65$ years old) made up $30.8 \%$ (49) of the study population, while the remaining $69.2 \%$ (110) were young and middle aged hypertensives. Of the elderly patients, $85.7 \%$ (42) had El, while $87.3 \%$ (110) of the young and middle aged had it. The baseline characteristics and presence of El is shown in Table 1.

El was more prevalent among females than males $(96.2 \%$ vs $82.1 \%$ in males; $p=0.002)$, patients who had tachycardia $(94.3 \%$ vs $80.9 \%$ of patients without tachycardia; $p=0.042$ ) and those with elevated DBP $(p=0.034)$. Table 2 shows Demographic/Clinical parameters and prevalence of El. Majority of patients had more than one electrolyte deranged: $39(24.5 \%)$ patients had more than two deranged electrolytes; $55(34.6 \%)$ had two deranged electrolytes, while 44(27.7\%) had one deranged electrolyte. Table 3 shows pattern of $\mathrm{El}$ and baseline characteristics. Figure 1 and 2 shows medication use and $\mathrm{El}$, while figure 3 shows complications and prevalence of El. Five (3.1\%) patients had cardiogenic shock, all of which had multiple Els.

The commonest electrolyte abnormality was hyponatremia seen in $63(39.6 \%)$ patients, followed by hypokalemia, reduced bicarbonate and hypochloremia found in 58 (36.5\%), 53(33.3\%), and $40(25.2 \%)$ respectively.

\section{Discussion}

Hypertension remains a very important public health issue globally with very worrying morbidity and mortality burden.[1,2] In the present retrospective study, we describe the prevalence and pattern of $\mathrm{El}$ in hypertensives hospitalized in three teaching hospitals in Nigeria.

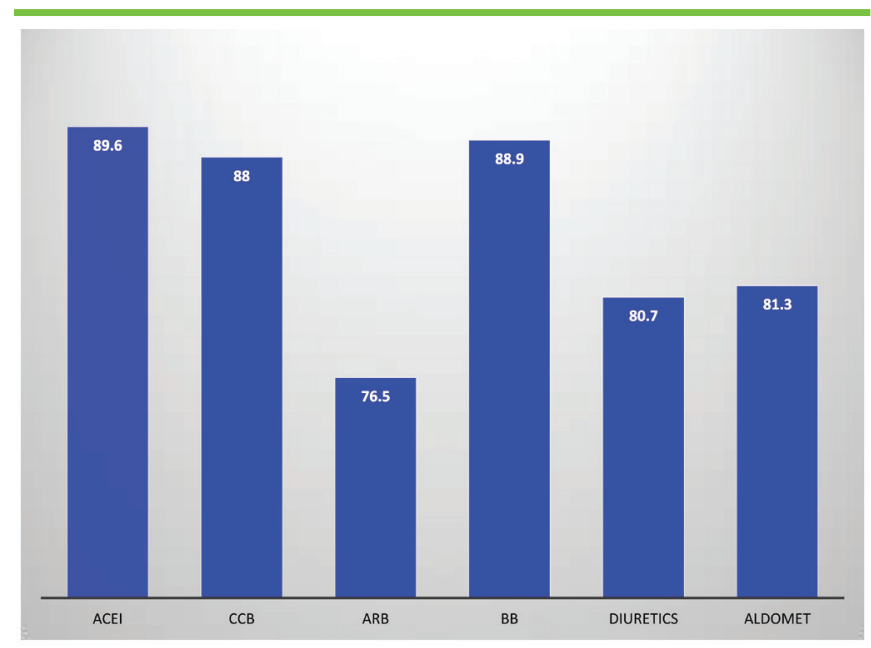

\section{Figure 1}

Prescribed medications and prevalence of electrolyte imbalances

ACEI- Angiotensin converting enzyme inhibitor; ARBAngiotensin receptor blockers. CCB: Calcium channel Blockers. BB- Beta Blockers. 
Table 1. Demographic and clinical parameters of patients with and without Electrolyte imbalances

\begin{tabular}{|l|l|l|l|}
\hline Variables & $\begin{array}{l}\text { Presence of } \\
\text { electrolyte } \\
\text { imbalance. } \\
\text { N=138 }(92.0 \%) \\
\text { Mean } \pm \text { SD }\end{array}$ & $\begin{array}{l}\text { Absence of } \\
\text { electrolyte } \\
\text { imbalance. } \\
\text { N=21(8.0\%) } \\
\text { Mean } \pm \text { SD }\end{array}$ & P \\
\hline Age (years) & $55.41 \pm 15.13$ & $56.33 \pm 16.34$ & 0.798 \\
\hline Systolic BP $(\mathrm{mmHg})$ & $146.10 \pm 36.38$ & $134.00 \pm 30.66$ & 0.150 \\
\hline Diastolic BP(mmHg) & $90.67 \pm 21.28$ & $81.90 \pm 13.57$ & 0.069 \\
\hline Heart rate (beats/min) & $98.25 \pm 16.54$ & $90.63 \pm 13.74$ & 0.059 \\
\hline
\end{tabular}

120

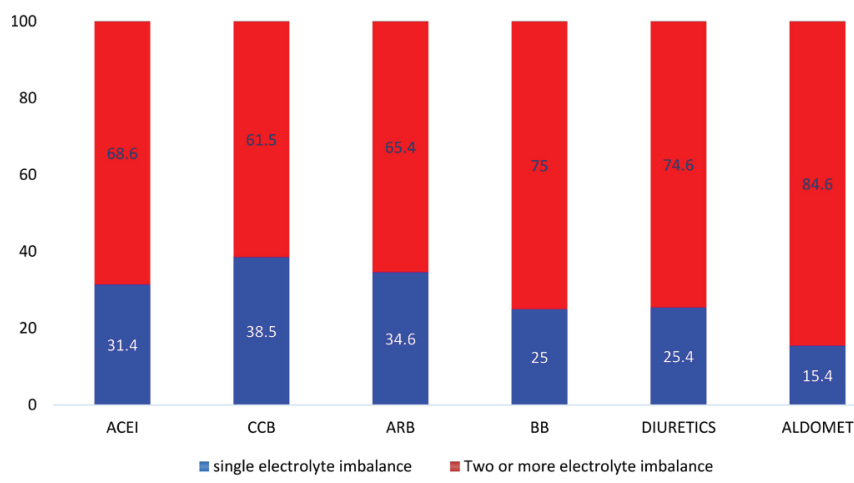

Figure 2: Medications used and number of electrolyte derangement

ACEI- Angiotensin converting enzyme inhibitor; ARBAngiotensin receptor blockers. CCB: Calcium channel Blockers. BB- Beta Blockers.

Firstly, this study showed that $\mathrm{El}$ is extremely common in hospitalized hypertensives. More than $85 \%$ of the patients had El, with over $65 \%$ of these having more than one deranged electrolyte. In a similar study among hospitalized diabetic patients, of which $61 \%$ had associated hypertension, electrolyte imbalance was reported in $78 \%$ of the patients [12]. The frequency of electrolyte derangement in these patients may be a reflection of the severity of their morbidity and should give a cause for concern $[4,12]$. Reasons that can account for EI in our patients include their medications like diuretics, Angiotensin converting enzyme inhibitors, Angiotensin receptor blockers and calcium channel blockers that are associated with electrolyte derangements [8-11]. More than $75 \%$ of our patients on each antihypertensive medication had $\mathrm{El}$, more than $60 \%$ of which were multiple Els. From this finding, it is obvious that placing patients on antihypertensive medications is not enough; they must have periodic electrolyte evaluation for early detection and prompt treatment of any El. Furthermore, complications like chronic renal failure, heart failure and stroke that patients present with can also account for Els [14-16]. All the patients in our study with complications had at least one El, most being multiple. Unfortunately, patients with complications are not only prone to developing Els, the presence of El in them sets up a vicious cycle, predisposing them to progression of the disease, other complications and worse outcomes [4,14-16]. The need for prevention and slowing down progression of complications cannot be overemphasized.

Patients with El had higher systolic BP, Diastolic BP and heart rate though not statistically significant. Perhaps a larger sample size would have uncovered the significance. Be that as it may, adequate control of these parameters will always impact on hypertensive patients, ultimately reducing the risk of complications, El, morbidity cum mortality.

This study also shows that El is significantly commoner in females, those with tachycardia, and elevated Diastolic blood pressure. Higher prevalence of Els in females has been reported in other cohort of patients $[17,21]$. This may be due to the effect of sex hormones on RAAS, metabolic and electrolyte homeostasis, making them more prone to Els [22]. Furthermore, increased cortisol levels in females with its' attendant effects on metabolic and electrolyte homeostasis may account for our findings [23,24]. The presence of various Els increases the risk of tachyarrhythmia and sympathetic overdrive which can explain the resultant tachycardia in these patients $[25,26]$. Furthermore, conditions that cause tachycardia like heart failure, stroke and renal failure with attendant vomiting and uremia can also result in Els [14-16,26]. Equally important is the fact that the RAAS system that play a major role in electrolyte homeostasis can predispose to cardiac remodeling, fibrosis and apoptosis with resultant tachyarrhythmia ranging from Sinus tachycardia, Supraventricular tachycardia to more fatal arrhythmias like ventricular tachycardia [27].

Hyponatremia is the commonest El in our study, present in

Table 2: Demographic/ clinical parameters and prevalence of Electrolyte imbalances

\begin{tabular}{|c|c|c|c|c|c|}
\hline Variables & Group & $\begin{array}{l}\text { Presence } \\
\text { of any El. } \\
\mathrm{N}=138 \\
(92.0 \%)\end{array}$ & $\begin{array}{l}\text { Absence of } \\
\text { any } \mathrm{El} \\
\mathrm{N}=21(8.0 \%)\end{array}$ & Total & $p$-value \\
\hline \multirow{2}{*}{ Gender } & & $51(96.2 \%)$ & $2(3.8 \%)$ & $\begin{array}{l}53 \\
(100.0 \%)\end{array}$ & \multirow{2}{*}{0.022} \\
\hline & Male & 87 (82.1\%) & 19 (17.9\%) & $\begin{array}{l}106 \\
(100.0 \%)\end{array}$ & \\
\hline \multirow{2}{*}{$\begin{array}{l}\text { Age } \\
\text { (years) }\end{array}$} & $<65$ & $96(87.3 \%)$ & $14(12.7 \%)$ & $\begin{array}{l}110 \\
(100.0 \%)\end{array}$ & \multirow{2}{*}{0.803} \\
\hline & $\geq 65$ & $42(85.7 \%)$ & $7(14.3 \%)$ & $\begin{array}{l}49 \\
(100.0 \%)\end{array}$ & \\
\hline \multirow[b]{2}{*}{$\begin{array}{l}\text { SBP } \\
(\mathrm{mmHg})\end{array}$} & $\geq 140$ & 85 (90.4\%) & $9(9.6 \%)$ & $\begin{array}{l}94 \\
(100.0 \%)\end{array}$ & \multirow[b]{2}{*}{0.116} \\
\hline & $<140$ & $53(81.5 \%)$ & 12 (18.5\%) & $\begin{array}{l}65 \\
(100.0 \%)\end{array}$ & \\
\hline \multirow{2}{*}{$\begin{array}{l}\text { DBP } \\
(\mathrm{mmHg})\end{array}$} & $\geq 90$ & 77 (92.8\%) & $6(7.2 \%)$ & $\begin{array}{l}83 \\
(100.0 \%)\end{array}$ & \multirow[b]{2}{*}{0.034} \\
\hline & $<90$ & $61(80.3 \%)$ & 15 (19.7\%) & $\begin{array}{l}76 \\
(100.0 \%)\end{array}$ & \\
\hline \multirow{2}{*}{$\begin{array}{l}\text { Heart } \\
\text { rate } \\
\text { (Beats/ } \\
\text { min) }\end{array}$} & $>100$ & $66(94.3 \%)$ & $4(5.7 \%)$ & $\begin{array}{l}70 \\
(100.0 \%)\end{array}$ & \multirow{2}{*}{0.042} \\
\hline & $\leq 100$ & 72 (80.9\%) & $17(19.1)$ & $\begin{array}{l}89 \\
(100.0 \%)\end{array}$ & \\
\hline
\end{tabular}

$\mathrm{SBP}=$ Systolic blood pressure. $\quad \mathrm{DBP}=$ Diastolic blood pressure 
Table 3: Number of electrolyte derangement and baseline characteristics.

\begin{tabular}{|c|c|c|c|c|c|c|c|}
\hline Parameters & Group & $\begin{array}{l}\text { No electrolyte } \\
\text { derangement }\end{array}$ & $\begin{array}{l}\text { One electrolyte } \\
\text { derangement }\end{array}$ & $\begin{array}{l}\text { Two electrolyte } \\
\text { derangement }\end{array}$ & $\begin{array}{l}\text { > Two } \\
\text { electrolyte } \\
\text { derangement }\end{array}$ & Total & $\mathrm{P}$ \\
\hline Age (years) & $\begin{array}{l}\geq 65 \\
<65\end{array}$ & $\begin{array}{l}7(14.3 \%) \\
14(12.7 \%)\end{array}$ & $\begin{array}{l}7(14.3 \%) \\
37(33.6 \%)\end{array}$ & $\begin{array}{l}22(44.9 \%) \\
33(30.0 \%)\end{array}$ & $\begin{array}{l}13(26.5 \%) \\
26(23.6 \%)\end{array}$ & $\begin{array}{l}\text { 49(100.0\%) } \\
110(69.2 \%)\end{array}$ & 0.072 \\
\hline Gender & $\begin{array}{l}\text { Female } \\
\text { Male }\end{array}$ & $\begin{array}{r}2(3.8 \%) \\
19(17.8 \%)\end{array}$ & $\begin{array}{l}21(40.4 \%) \\
23(21.5 \%)\end{array}$ & $\begin{array}{l}12(23.1 \%) \\
43(40.2 \%)\end{array}$ & $\begin{array}{l}17(32.7 \%) \\
22(20.6 \%)\end{array}$ & $\begin{array}{l}52(100.0 \%) \\
107(100.0 \%)\end{array}$ & 0.001 \\
\hline Systolic BP (mmHg) & $\begin{array}{l}\geq 140 \\
<140 \\
\end{array}$ & $\begin{array}{c}9(9.6 \%) \\
12(18.5 \%) \\
\end{array}$ & $\begin{array}{l}32(34.0 \%) \\
12(18.5 \%) \\
\end{array}$ & $\begin{array}{l}29(30.9 \%) \\
26(40.0 \%) \\
\end{array}$ & $\begin{array}{l}24(25.5 \%) \\
15(23.0 \%) \\
\end{array}$ & $\begin{array}{l}94(100.0 \%) \\
65(100.0 \%)\end{array}$ & 0.063 \\
\hline Diastolic BP (mmHg) & $\begin{array}{l}\geq 90 \\
<90\end{array}$ & $\begin{array}{r}6(7.2 \%) \\
15(19.7 \%)\end{array}$ & $\begin{array}{l}30(36.1 \%) \\
14(18.4 \%)\end{array}$ & $\begin{array}{l}26(31.3 \%) \\
29(38.2 \%)\end{array}$ & $\begin{array}{l}21(25.3 \%) \\
18(23.7 \%)\end{array}$ & $\begin{array}{l}83(100.0 \%) \\
76(100.0 \%)\end{array}$ & 0.003 \\
\hline Heart rate (beats $/ \mathrm{min}$ ) & $\begin{array}{l}>100 \\
\leq 100\end{array}$ & $\begin{array}{c}5(7.2 \%) \\
17(19.1 \%)\end{array}$ & $\begin{array}{l}21(30.0 \%) \\
21(23.6 \%)\end{array}$ & $\begin{array}{l}26(37.1 \%) \\
32(36.0 \%)\end{array}$ & $\begin{array}{l}18(25.7 \%) \\
19(21.3 \%)\end{array}$ & $\begin{array}{l}70(100.0 \%) \\
89(100.0 \%)\end{array}$ & 0.178 \\
\hline
\end{tabular}

about $40 \%$ of patients. Similar report was seen in hospitalized diabetics, patients in ICU and emergency department [12,17]. Hyponatremia is the most common electrolyte abnormality in hospitalized patients [17]. Several factors can be responsible for this, ranging from heart failure, [14] syndrome of inappropriate secretion of antidiuretic hormone (SIADH) or cerebral salt wasting syndrome in stroke patients, to secondary adrenal insufficiency [28]. Other causes are drugs like diuretics, renal pathology and salt restriction as part of management for hypertension [28]. Despite the fact that hyponatremia can increase morbidity and mortality in patients, the condition is often underdiagnosed and insufficiently treated $[6,14,17]$. The need for serial assessment and prompt, adequate treatment is critical.

We also noticed that patients with tachycardia had significantly higher prevalence of hyponatremia, this may either be a cause or effect situation. While hyponatremia predisposes to tachyarrhythmia of various types, tachycardia on the other hand can trigger a cascade that can ultimately cause hyponatremia. [29] The presence of tachycardia is a poor prognostic factor in cardiovascular disease, causing increasing cardiac events and mortality, it is therefore not enough to control blood pressure, achieving normal heart rate is equally important and can be lifesaving.[29,30]

Hypokalemia was noticed in about $36 \%$ of our patients. Hypokalemia is common in hypertensive patients, being itself a risk factor for hypertension [4,5]. Hypokalemia is also common in patients with other chronic diseases [12,14-16]. Possible cause of hypokalemia include inadequate intake of potassium containing foods like fruits, increased excretion from use of drugs like thiazide diuretics, vomiting or diarrhea, associated primary or secondary hyperaldosteronism which are not uncommon in hypertension [15,31]. Hypokalemia can add to the morbidity of patients, contributing to the fatigue, leg cramps, palpitations, exercise intolerance and weakness that patients complain of [31]. Furthermore, hypokalemia is a poor prognostic factor that can result in worsening insulin resistance, worsening endothelial function, arrhythmia, worsening renal functions with attendant diabetes insipidus and metabolic acidosis [31]. Identification and prompt treatment of hypokalemia can prevent life-threatening complications and improve the outcome of patients [15,31].

On the other hand, $15 \%$ of our patients had hyperkalemia. Hyperkalemia is not uncommon in hypertensive patients, [15] although quite difficult to diagnose because it is often either clinically quiescent or present with non-specific symptoms [15,32]. It is not surprising that majority of patients with associated renal pathology had hyperkalemia in our study, in keeping with findings in literature [15,32]. Other possible etiology in our patients includes use of ACE inhibitors, Angiotensin receptor blocker, spironolactone a potassium sparing diuretics, B blockers, and adrenal insufficiency [32]. Patients may present with weakness, fatigue, palpitations, parasthesia and in severe cases sudden

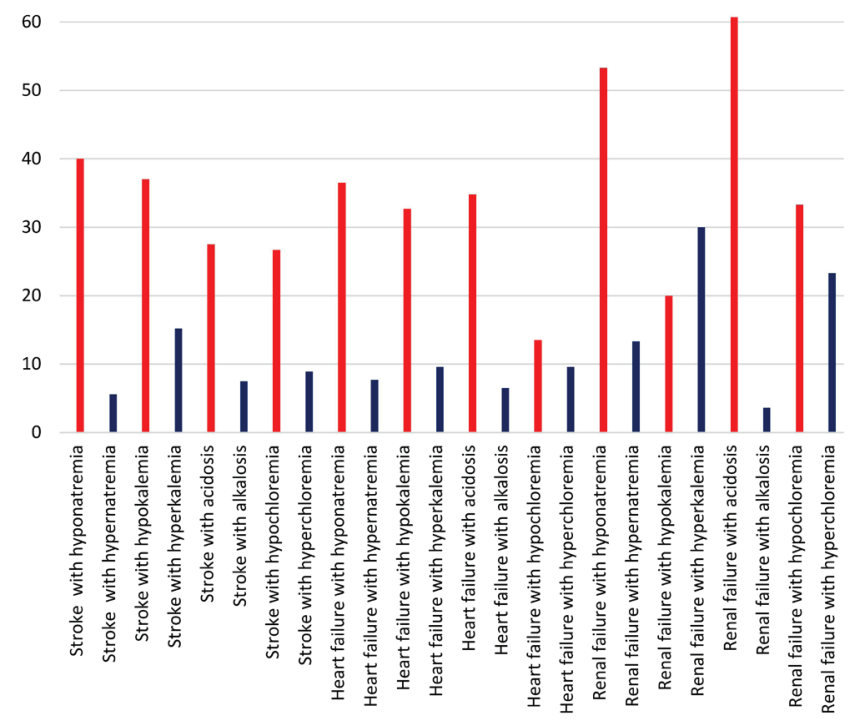

Figure 3. Complications and \% of Electrolyte imbalance 


\section{Table 4: Baseline characteristics and serum sodium levels}

\begin{tabular}{|c|c|c|c|c|c|c|}
\hline \multirow{2}{*}{ Parameters } & \multirow{2}{*}{ Group } & \multicolumn{3}{|c|}{ Sodium levels (mmols/l) } & \multirow{2}{*}{ Total } & \multirow{2}{*}{$\mathbf{P}$} \\
\hline & & $\geq 145$ & $135-145$ & $<135$ & & \\
\hline $\begin{array}{l}\text { Age } \\
\text { (Years) }\end{array}$ & $\begin{array}{l}\geq 65 \\
<65\end{array}$ & $\begin{array}{l}3(6.1 \%) \\
9(8.2 \%)\end{array}$ & $\begin{array}{l}23(46.9 \%) \\
61(55.5 \%)\end{array}$ & $\begin{array}{l}23(26.9 \%) \\
40(36.4 \%)\end{array}$ & $\begin{array}{l}49(100.0 \%) \\
110(100.0 \%)\end{array}$ & 0.447 \\
\hline Gender & $\begin{array}{l}\text { Female } \\
\text { Male }\end{array}$ & $\begin{array}{l}3(5.8 \%) \\
9(8.4 \%)\end{array}$ & $\begin{array}{l}28(53.8 \%) \\
56(52.3 \%)\end{array}$ & $\begin{array}{l}21(40.4 \%) \\
42(39.3 \%)\end{array}$ & $\begin{array}{l}52(100.0 \%) \\
107(100.0 \%)\end{array}$ & 0.831 \\
\hline $\begin{array}{l}\text { Systolic BP } \\
(\mathrm{mmHg})\end{array}$ & $\begin{array}{l}\geq 140 \\
<140\end{array}$ & $\begin{array}{l}5(5.3 \%) \\
7(10.8 \%)\end{array}$ & $\begin{array}{l}55(58.5 \%) \\
29(44.6 \%)\end{array}$ & $\begin{array}{l}34(36.2 \%) \\
29(44.6 \%)\end{array}$ & $\begin{array}{l}94(100.0 \%) \\
65(100.0 \%)\end{array}$ & 0.036 \\
\hline $\begin{array}{l}\text { Diastolic BP } \\
(\mathrm{mmHg})\end{array}$ & $\begin{array}{l}\geq 90 \\
<90\end{array}$ & $\begin{array}{l}5(6.0 \%) \\
7(9.2 \%)\end{array}$ & $\begin{array}{l}48(57.8 \%) \\
36(47.4 \%)\end{array}$ & $\begin{array}{l}30(36.1 \%) \\
33(43.4 \%)\end{array}$ & $\begin{array}{l}83(100.0 \%) \\
76(100.0 \%)\end{array}$ & 0.265 \\
\hline $\begin{array}{l}\text { Heart Rate } \\
\text { (beats/min) }\end{array}$ & $\begin{array}{l}>100 \\
\leq 100\end{array}$ & $\begin{array}{l}3(5.7 \%) \\
9(11.2 \%)\end{array}$ & $\begin{array}{l}31(42.9 \%) \\
53(58.4 \%)\end{array}$ & $\begin{array}{l}36(51.4 \%) \\
27(30.4 \%)\end{array}$ & $\begin{array}{l}70(100.0 \%) \\
89(100.0 \%)\end{array}$ & 0.028 \\
\hline
\end{tabular}

death from fatal arrhythmia [15,32]. Hyperkalemia is associated with increased morbidity and mortality in patients, serial serum potassium test is therefore important for early diagnosis and treatment $[15,32]$.

Maintaining a good acid-base balance is essential for optimal health and functions of the organs of the body. Low bicarbonate levels in the blood are a sign of metabolic acidosis, and this was present in over $33 \%$ of patients in our study. Previous studies have found an association between metabolic acidosis, hypertension and cardiovascular diseases [33,34]. Our study seems to corroborate this as over $60 \%, 30 \%$ and $25 \%$ of renal failure, heart failure and stroke patients had metabolic acidosis respectively. Possible causes of metabolic acidosis in our patients includes increased salt intake, fatty foods, processed foods, alcohol, red meat, sodas, and reduced consumption of alkaline substances like fruits and vegetables. [35] Other possible causes include increased excretion of bicarbonate, decreased $\mathrm{H}_{+}$ excretion, hypoaldosteronism, infection and use of salicylate etc [33-34]. Metabolic acidosis can cause sympathetic overdrive and stimulation of the Renin Angiotensin Aldosterone system (RAAS) with resultant vasoconstriction, elevated $\mathrm{BP}$, tachycardia and arrhythmia $[33,35]$. This may explain our finding where patients with metabolic acidosis were more likely to have elevated BP and tachycardia. Metabolic acidosis is not only a negative prognostic factor of cardiovascular diseases, it can also result in a number of comorbidities like osteoporosis, cirrhosis, diabetes mellitus, renal diseases, increased risk of infection etc [33,35]. Prompt recognition and correction is important to improve the prognosis of patients.

Elevated bicarbonate, a marker of metabolic alkalosis, was present in about $9 \%$ of our patients. Causes can include vomiting, use of diuretics, hyperaldosteronism and antacids [36]. Also,

Table 5: Baseline characteristics and serum Potassium levels.

\begin{tabular}{|c|c|c|c|c|c|c|}
\hline \multirow{2}{*}{ Parameter } & \multirow{2}{*}{ Group } & \multicolumn{3}{|c|}{ Potassium (mmol/L) } & \multirow{2}{*}{ Total } & \multirow{2}{*}{$P$} \\
\hline & & $>5$ & $3.5-5.0$ & $<3.5$ & & \\
\hline Age (Years) & $\begin{array}{l}\geq 65 \\
<65\end{array}$ & $\begin{array}{l}8(16.3 \%) \\
16(14.5 \%)\end{array}$ & $\begin{array}{l}21(42.9 \%) \\
56(50.9 \%)\end{array}$ & $\begin{array}{l}20(40.8 \%) \\
38(34.6 \%)\end{array}$ & $\begin{array}{l}49(100.0 \%) \\
110(100.0 \%)\end{array}$ & 0.641 \\
\hline Gender & $\begin{array}{l}\text { Female } \\
\text { Male }\end{array}$ & $\begin{array}{l}12(23.1 \%) \\
12(11.2 \%)\end{array}$ & $\begin{array}{l}19(36.5 \%) \\
58(54.2 \%)\end{array}$ & $\begin{array}{l}21(40.4 \%) \\
37(34.6 \%)\end{array}$ & $\begin{array}{l}52(100.0 \%) \\
107(100.0 \%)\end{array}$ & 0.051 \\
\hline $\begin{array}{l}\text { Systolic BP } \\
(\mathrm{mmHg})\end{array}$ & $\begin{array}{l}\geq 140 \\
<140\end{array}$ & $\begin{array}{l}16(17.0 \%) \\
8(12.3 \%)\end{array}$ & $\begin{array}{l}48(51.1 \%) \\
29(44.6 \%)\end{array}$ & $\begin{array}{l}30(31.9 \%) \\
28(43.1 \%)\end{array}$ & $\begin{array}{l}94(100.0 \%) \\
65(100.0 \%)\end{array}$ & 0.101 \\
\hline $\begin{array}{l}\text { Diastolic BP } \\
(\mathrm{mmHg})\end{array}$ & $\begin{array}{l}\geq 90 \\
<90\end{array}$ & $\begin{array}{l}13(15.7 \%) \\
11(14.5 \%)\end{array}$ & $\begin{array}{l}44(53.0 \%) \\
33(43.4 \%)\end{array}$ & $\begin{array}{l}26(31.3 \%) \\
32(42.1 \%)\end{array}$ & $\begin{array}{l}83(100.0 \%) \\
76(100.0 \%)\end{array}$ & 0.285 \\
\hline $\begin{array}{l}\text { Heart rate } \\
\text { (beats/min) }\end{array}$ & $\begin{array}{l}>100 \\
\leq 100\end{array}$ & $\begin{array}{l}7(10.0 \%) \\
17(19.1 \%)\end{array}$ & $\begin{array}{l}32(45.7 \%) \\
45(50.6 \%)\end{array}$ & $\begin{array}{l}31(44.3 \%) \\
27(30.3 \%)\end{array}$ & $\begin{array}{l}70(100.0 \%) \\
89(100.0 \%)\end{array}$ & 0.150 \\
\hline
\end{tabular}




\begin{tabular}{|c|c|c|c|c|c|c|}
\hline \multirow{2}{*}{ Parameter } & \multirow{2}{*}{ Group } & \multicolumn{3}{|c|}{ Chloride level (mmol/L) } & \multirow{2}{*}{ Total } & \multirow{2}{*}{$\mathbf{P}$} \\
\hline & & $>106$ & $96-106$ & $<96$ & & \\
\hline Age (years) & $\begin{array}{l}\geq 65 \\
<65\end{array}$ & $\begin{array}{l}7(14.3 \%) \\
16(14.6 \%)\end{array}$ & $\begin{array}{l}27(55.1 \%) \\
69(62.7 \%)\end{array}$ & $\begin{array}{l}15(30.6 \%) \\
25(22.7 \%)\end{array}$ & $\begin{array}{l}49(100.0 \%) \\
110(100.0 \%)\end{array}$ & 0.558 \\
\hline Gender & $\begin{array}{l}\text { Female } \\
\text { Male }\end{array}$ & $\begin{array}{l}4(7.7 \%) \\
19(17.8 \%)\end{array}$ & $\begin{array}{l}26(50.0 \%) \\
70(65.4 \%)\end{array}$ & $\begin{array}{l}22(42.3 \%) \\
18(16.7 \%)\end{array}$ & $\begin{array}{l}52(100.0 \%) \\
107(100.0 \%)\end{array}$ & 0.002 \\
\hline $\begin{array}{l}\text { Systolic BP } \\
(\mathrm{mmHg})\end{array}$ & $\begin{array}{l}\geq 140 \\
<140\end{array}$ & $\begin{array}{l}17(18.1 \%) \\
6(9.2 \%)\end{array}$ & $\begin{array}{l}52(55.3 \%) \\
44(67.7 \%)\end{array}$ & $\begin{array}{l}25(26.6 \%) \\
15(23.1 \%)\end{array}$ & $\begin{array}{l}94(100.0 \%) \\
65(100.0 \%)\end{array}$ & 0.115 \\
\hline $\begin{array}{l}\text { Diastolic BP } \\
(\mathrm{mmHg})\end{array}$ & $\begin{array}{l}\geq 90 \\
<90\end{array}$ & $\begin{array}{l}16(19.3 \%) \\
7(9.2 \%)\end{array}$ & $\begin{array}{l}47(56.6 \%) \\
49(64.5 \%)\end{array}$ & $\begin{array}{l}20(24.1 \%) \\
20(26.3 \%)\end{array}$ & $\begin{array}{l}83(100.0 \%) \\
76(100.0 \%)\end{array}$ & 0.002 \\
\hline $\begin{array}{l}\text { Heart rate } \\
\text { (beats/min) }\end{array}$ & $\begin{array}{l}>100 \\
\leq 100\end{array}$ & $\begin{array}{l}10(14.3 \%) \\
13(14.6 \%)\end{array}$ & $\begin{array}{l}41(58.6 \%) \\
60(67.4 \%)\end{array}$ & $\begin{array}{l}19(27.1 \%) \\
16(18.0 \%)\end{array}$ & $\begin{array}{l}70(100.0 \%) \\
89(100.0 \%)\end{array}$ & 0.378 \\
\hline
\end{tabular}

\section{Table 7: Baseline characteristics and serum Bicarbonate levels}

\begin{tabular}{|c|c|c|c|c|c|c|}
\hline \multirow{2}{*}{ Parameter } & \multirow{2}{*}{ Group } & \multicolumn{3}{|c|}{ Bicarbonate (mmol/L) } & \multirow{2}{*}{ Total } & \multirow{2}{*}{$\mathbf{P}$} \\
\hline & & $>30$ & $22-30$ & $<22$ & & \\
\hline Age(years) & $\begin{array}{l}\geq 65 \\
<65\end{array}$ & $\begin{array}{l}7(14.3 \%) \\
7(6.4 \%)\end{array}$ & $\begin{array}{l}30(61.2 \%) \\
62(56.3 \%)\end{array}$ & $\begin{array}{l}12(24.5 \%) \\
41(37.3 \%)\end{array}$ & $\begin{array}{l}49(100.0 \%) \\
110(100.0 \%)\end{array}$ & 0.140 \\
\hline Gender & $\begin{array}{l}\text { Female } \\
\text { Male }\end{array}$ & $\begin{array}{l}3(5.8 \%) \\
11(10.3 \%)\end{array}$ & $\begin{array}{l}30(57.7 \%) \\
62(57.9 \%)\end{array}$ & $\begin{array}{l}19(36.5 \%) \\
34(31.8 \%)\end{array}$ & $\begin{array}{l}52(100.0 \%) \\
107(100.0 \%)\end{array}$ & 0.438 \\
\hline $\begin{array}{l}\text { Systolic BP } \\
(\mathrm{mmHg})\end{array}$ & $\begin{array}{l}\geq 140 \\
<140\end{array}$ & $\begin{array}{l}5(5.3 \%) \\
9(13.8 \%)\end{array}$ & $\begin{array}{l}50(53.2 \%) \\
42(64.6 \%)\end{array}$ & $\begin{array}{l}39(41.5 \%) \\
14(21.5 \%)\end{array}$ & $\begin{array}{l}94(100.0 \%) \\
65(100.0 \%)\end{array}$ & 0.037 \\
\hline $\begin{array}{l}\text { Diastolic BP } \\
\mathrm{mmHg}\end{array}$ & $\begin{array}{l}\geq 90 \\
<90\end{array}$ & $\begin{array}{l}5(6.0 \%) \\
9(11.8 \%)\end{array}$ & $\begin{array}{l}41(49.4 \%) \\
51(67.1 \%)\end{array}$ & $\begin{array}{l}37(44.6 \%) \\
16(21.1 \%)\end{array}$ & $\begin{array}{l}83(100.0 \%) \\
76(100.0 \%)\end{array}$ & 0.003 \\
\hline $\begin{array}{l}\text { Heart rate } \\
\text { (beats/min) }\end{array}$ & $\begin{array}{l}>100 \\
\leq 100\end{array}$ & $\begin{array}{l}1(1.4 \%) \\
13(14.6 \%)\end{array}$ & $\begin{array}{l}41(58.6 \%) \\
51(57.3 \%)\end{array}$ & $\begin{array}{l}28(40.0 \%) \\
25(28.1 \%)\end{array}$ & $\begin{array}{l}70(100.0 \%) \\
89(100.0 \%)\end{array}$ & 0.006 \\
\hline
\end{tabular}

hypokalemia can indirectly predispose patients to metabolic alkalosis by causing enhanced proximal bicarbonate absorption, intracellular movement of Hydrogen ion in replacement of extracellular movement of potassium [36]. Detection and prompt treatment is important as patients can have very grave features from muscle weakness, confusion, seizures to coma; arrhythmia and syncope [36,37]. Equally important is the fact that associated electrolyte abnormalities like hypochloremia, hypokalemia, and hypocalcemia that tend to occur with metabolic alkalosis need to be identified and promptly treated as well to improve outcome [37].

Serum chloride is an important electrolyte and the most abundant extracellular anion in the body, however, it has received less attention than other electrolyte. [38]. Hypo and hyperchloremia were present in $25 \%$ and $14.5 \%$ of our patients respectively. Serum chloride abnormality has been identified in other hospitalized patients, and found to be associated with poor prognosis and mortality [38]. Serum chloride derangement, as observed in our study, is usually associated with other electrolyte derangement and acid-base imbalance, [38] with hypochloremia more associated with hyponatremia, hypokalemia and alkalosis, while hyperchloremia is associated with metabolic acidosis, hypernatremia and hyperkalemia [38]. The presence of multiple electrolyte derangement in such scenarios is associated with worse morbidity and mortality, further underscoring the need for prompt diagnosis and management.

Also important to note is that patients with cardiogenic shock, though very few in this study $(3.1 \%)$ all had multiple Els. This is not surprising, since this is the end stage of the spectrum, usually called burnt out hypertension, and it represent a scenario of hypoperfusion with multiple organ dysfunction like secondary adrenal insufficiency, worsening renal, neurologic and cardiac 
dysfunction. This state is associated with very high morbidity and mortality, not only from the complications but also from the impact of the multiple Els [39].

\section{Limitations of the study}

This is a retrospective study and therefore has its draw backs. Missing data leading to the non-inclusion of such patients clearly reduced the sample size with possible reduction in the robustness of the result. The need for adequate data keeping with the use of digital technology cannot be overemphasized.

Blood gases were not done in most of the patients, therefore making the diagnosis of metabolic acidosis and alkalosis solely dependent on bicarbonate level. Also, other equally important electrolytes like serum Calcium, Magnesium, Phosphorus were not assessed in our patients. Finally, it is important to emphasize that arterial rather than venous electrolyte concentration correlate best with physiologic effects of various electrolytes.

In Conclusion, electrolyte imbalance is very common in hospitalized hypertensive patients, hypertension complications must not only be diagnosed and treated in these patients, the need for regular monitoring of electrolyte, prompt detection and correction of any imbalance is equally very important in their management.

\section{Declarations of interest}

The authors declare no conflicts of interest.

\section{Acknowledgements}

We thank the personnel in the ward and Medical records department for their assistance during data collection. The authors state that they abide by the "Requirements for Ethical Publishing in Biomedical Journals" [40].

\section{References}

1. World Health Organization. A global brief on Hypertension. Silent killer, global public health crisis. World Health Day 2013. Geneva, World Health Organization, 2013.

2. Olusegun-Joseph AD, Karaye KM, Akintunde AA, Okunowo BO, Opadijo OG, Habib AG, Balarabe SA. Profile of Hospitalized Hypertensives with Preserved and Reduced Left Ventricular Ejection Fraction in Nigeria: International Cardiovascular Forum Journal. 2018;14:11-15. DOI: 10.17987/ icfj.v14i0.502

3. Lim SS, Vos T, Flaxman AD, Danaei G, et al A comparative risk assessment of burden of disease and injury attributable to 67 risk factors and risk factor clusters in 21 regions, 1990-2010: a systematic analysis for the Global Burden of Disease Study 2010. Lancet. 2012; 380 (9859): 2224-60.

4. Iqbal S, Klammer N, Ekmekcioglu C. The Effect of Electrolytes on Blood Pressure: A Brief Summary of Meta-Analyses. Nutrients. 2019;11(6):1362. Published 2019 Jun 17.doi:10.3390/nu11061362

5. Gijsbers, L., Dower, J., Mensink, M. et al. Effects of sodium and potassium supplementation on blood pressure and arterial stiffness: a fully controlled dietary intervention study. J Hum Hypertens 29, 592-598 (2015). https:// doi.org/10.1038/jhh.2015.3

6. Mohan S, Gu S, Parikh A, Radhakrishnan J. Prevalence of hyponatremia and association with mortality: results from NHANES. Am $\mathrm{J}$ Med. 2013;126(12):1127-37.e1. doi:10.1016/j.amjmed.2013.07.021.

7. Takahashi H, Yoshika M, Komiyama Y, Nishimura M. The central mechanism underlying hypertension: a review of the roles of sodium ions, epithelial sodium channels, the renin-angiotensin-aldosterone system, oxidative stress and endogenous digitalis in the brain. Hypertens Res. 2011;34(11):1147-1160. doi:10.1038/hr.2011.105.

8. Liamis $\mathrm{G}$, Milionis H, Elisaf M. Blood pressure drug therapy and electrolyte disturbances. Int J Clin Pract. 2008;62:1572-1580.

9. Te Riet L, van Esch JH, Roks AJ, van den Meiracker AH, Danser $A H$. Hypertension: renin-angiotensin-aldosterone system alterations. Circ Res. 2015; 116:960-975.

10. Kolber MR, Garrison S, Turgeon RD. Electrolyte disturbance with diuretics and ACEls. Can Fam Physician. 2016;62(7):569.
11. Leonetti G. The effects of calcium antagonists on electrolytes and water balance in hypertensive patients. J Cardiovasc Pharm 1994; 24 Suppl. A: S25-9.

12. Haque F, Amin MG, Usim KN, Samad T, etal. Pattern of Electrolyte Imbalance in Hospitalized Diabetic Patients: Experience in a Tertiary Care Hospital. Birdem Med J, 2012;2(1):1-5. DOI:10.3329/birdem.v2il.1235.

13. Pandey V, Dutt HK, Singh G, Vinod AP. Correlation of blood Na+ and K+ levels with Body Mass Index in population of Garhwal region of Uttarakhand. J App Pharm Sci, 2017; 7 (01): 189-192.

14. Shorr AF, Tabak YP, Johannes RS, Gupta V, Saltzberg MT, Costanzo MR. Burden of sodium abnormalities in patients hospitalized for heart failure. Congest Heart Fail. 2011;17(1):1-7. Epub 2011/01/29. pmid:21272220.

15. Cheungpasitporn W, Thongprayoon C, Kittanamongkolchai W, Sakhuja A, Mao MA, Erickson SB. Impact of admission serum potassium on mortality in patients with chronic kidney disease and cardiovascular disease. QJM. 2017;110(11):713-9. Epub 2017/06/24. pmid:28637264.

16. Bandyopadhyay M, Jatua SK, Adhikari M, Bhandari A. Study of Electrolyte Abnormality in Acute Stroke. Ann. Int. Med. Den. Res. 2017; 3(5):ME04ME09.

17. Tazmini K, Nymo SH, Louch WE, Ranhoff AH, Øie E. Electrolyte imbalances in an unselected population in an emergency department: A retrospective cohort study. PLOS ONE 2019;14(4): e0215673. https://doi.org/10.1371/ journal.pone.0215673.

18. Chobanian AV, Bakris GL, Black HR, et al. Seventh report of the Joint National Committee on Prevention, Detection, Evaluation, and Treatment of High Blood Pressure. Hypertension. 2003; 42(6):1206-52.

19. Stoppler MS, Shiel WC. Electrolytes. MedicineNet. 2019. https://www. medicinenet. com/electrolytes/article.htm.

20. Laboratory Values. The Clinicians ultimate reference. Globalrph. http:// www.globalrph. com/labs.htm.

21. Lindner G, Pfortmüller CA, Leichtle AB, Fiedler G M, Exadaktylos AK. Age-Related Variety in Electrolyte Levels and Prevalence of Dysnatremias and Dyskalemias in Patients Presenting to the Emergency Department. Gerontology 2014;60:420-423. doi: 10.1159/000360134.

22. Oelkers WK. Effects of estrogens and progestogens on the reninaldosterone system and blood pressure. Steroids. 1996;61(4):166-171. doi:10.1016/0039-128x(96)00007-4

23. Larsson, C.A., Gullberg, B., Råstam, L. et al. Salivary cortisol differs with age and sex and shows inverse associations with WHR in Swedish women: a cross-sectional study. BMC Endocr Disord 9, 16 (2009). https://doi. org/10.1186/1472-6823-9-16.

24. Lianne M. Kurina, Lauren A. Weiss, Steven W. Graves, Rodney Parry, Gordon H. Williams, Mark Abney, Carole Ober, Sex Diffe ences in the Genetic Basis of Morning Serum Cortisol Levels: Genome-Wide Screen Identifies Two Novel Loci Specific to Women, The Journal of Clinical Endocrinology \& Metabolism, Volume 90, Issue 8, 1 August 2005, Pages 4747-4752, https://doi.org/10.1210/jc.2005-0384.

25. Caralis PV, Perez-Stable E. Electrolyte abnormalities and ventricular arrhythmias. Drugs. 1986;31 Suppl 4:85-100. doi:10.2165/00003495198600314-00011.

26. Skogestad J, Aronsen JM. Hypokalemia-Induced Arrhythmias and Heart Failure: New Insights and Implications for Therapy. Front Physiol. 2018;9:1500. Published 2018 Nov 7. doi:10.3389/fphys.2018.01500.

27. Iravanian S, Dudley SC Jr. The renin-angiotensin-aldosterone system (RAAS) and cardiac arrhythmias. Heart Rhythm. 2008 Jun;5(6 Suppl):S12-7. DOI: 10.1016/j.hrthm.2008.02.025.

28. Hoorn EJ, Zietse R. Diagnosis and Treatment of Hyponatremia: Compilation of the Guidelines. J Am Soc Nephrol. 2017;28(5):1340-1349. doi:10.1681/ ASN.2016101139.

29. Cierpka-Kmieć K, Hering D. Tachycardia: The hidden cardiovascular risk factor in uncomplicated arterial hypertension [published online ahead of print, 2019 Feb 25]. Cardiol J. 2019;10.5603/CJ.a2019.0021. doi:10.5603/ CJ.a2019.0021.

30. Paul L, Hastie CE, Li WS, et al. Resting heart rate pattern during follow-up and mortality in hypertensive patients. Hypertension. 2010;55(2):567-574. doi:10.1161/HYPERTENSIONAHA.109. 144808.

31. Kardalas E, Paschou SA, Anagnostis P, Muscogiuri G, Siasos G, Vryonidou A. Hypokalemia: a clinical update. Endocr Connect. 2018;7(4):R135-R146. doi:10.1530/EC-18-0109.

32. Simon LV, Hashmi MF, Farrell MW. Hyperkalemia. In: StatPearls, Treasure Island (FL): StatPearls Publishing; 2020 Jan-. Available from: https://www. ncbi.nlm.nih.gov/ books/NBK470284/.

33. Mandel El, Forman JP, Curhan GC, Taylor EN. Plasma bicarbonate and odds of incident hypertension. Am J Hypertens. 2013;26(12):1405-1412. doi:10.1093/ajh/hpt133.

34. Stancu S, Mircescu G, Mocanu A, Capusa C, Stefan G. Metabolic Acidosis of Chronic Kidney Disease and Cardiovascular Disorders. Maedica (Bucur). 2018;13(4):267-272. doi:10.26574/maedica.2018. 13.4.267.

35. Carnauba RA, Baptistella AB, Paschoal V, Hübscher GH. Diet-Induced LowGrade Metabolic Acidosis and Clinical Outcomes: A Review. Nutrients. 2017;9(6):538. Published 2017 May 25. doi:10.3390/nu9060538.

36. Thomas CP, Yaseen S. Metabolic alkalosis. Emedicine, 2018. https:// emedicine.medscape. com/article/243160. 
37. Dhondup T, Qian Q. Acid-Base and Electrolyte Disorders in Patients with and without Chronic Kidney Disease: An Update. Kidney Dis (Basel). 2017;3(4):136-148.

38. Makiko Tani, Hiroshi Morimatsu, Fumiaki Takatsu, Kiyoshi Morita, "The Incidence and Prognostic Value of Hypochloremia in Critically III Patients", The Scientific World Journal, vol. 2012, Article ID 474185, 7 pages, 2012. https://doi.org/10.1100/2012/474185.

39. Vahdatpour C, Collins D, Goldberg S. Cardiogenic Shock. J Am Heart Assoc. 2019 Apr 16;8(8):e011991. doi: 10.1161/JAHA.119.011991. PMID: 30947630; PMCID: PMC6507212.

40. Shewan LG, Coats AJS, Henein MY. Authors' Responsibilities and Ethical Publishing. International Cardiovascular Forum Journal 2018;13:3-4. DOI: 10.17987/icfj.v13i0.525. 